\title{
Predictive scenarios for surface water quality simulation - A watershed case study
}

\author{
I.M.H.R. Antunes ${ }^{\mathrm{a}, *}$, M.T.D. Albuquerque ${ }^{\mathrm{b}}$, S.F. Oliveira ${ }^{\mathrm{b}}$, G. Sánz ${ }^{\mathrm{c}}$ \\ ${ }^{a}$ ICT/University of Minho. Campus de Gualtar, 4710-057 Braga, Portugal \\ b Instituto Politécnico de Castelo Branco, Castelo Branco, Portugal \\ ${ }^{\mathrm{c}}$ European University of Miguel de Cervantes, Valladolid, Spain
}

\section{A R T I C L E I N F O}

\section{Keywords:}

Águeda River

Basin

Fresh water

Portugal-Spain

Qual2Kw

Self-depuration

\begin{abstract}
A B S T R A C T
Surface water is exposed to contaminants which change the natural hydrological parameters and consequent contaminant dispersion. Water self-depuration is an ecological process aiming to restore the natural watercourse balance, which depends on the quality and quantity of topical and diffuse contributions. The main goal of this research is the evaluation of surface water quality in the Águeda River (Portugal-Spain transboundary watershed) and its self-depuration ability considering different predicted scenarios. Biochemical oxygen demand $\left(\mathrm{BOD}_{5}\right)$, dissolved oxygen (DO), dry residue, Ptotal, Ntotal, $\mathrm{pH}$, temperature and microbiological parameters were analyzed, in thirty-six surface water samples.

Simulation of different quality scenarios was undertaken using Qual2Kw software and the river's self-depuration ability discussed. The obtained model's calibration achieved a score of $95 \%$ confidence interval, for almost analyzed parameters. The calibrated model was used for two prediction scenario construction. The first one, intending to assess the influence of topical contaminated discharge and the second one, aiming to evaluate the influence of minimum flow rates, representing an extremely dry year. The two considered scenarios revealed that self-depuration capacity is more affected by the presence of minimum flow rates than topical discharges, attesting a large potential for self-depuration along the Águeda River.
\end{abstract}

\section{Introduction}

Stream water quality is regulated by a complex suite of anthropogenic activities and natural processes, which could be directly or indirectly influenced by surface activities (e.g., Pratt and Chang, 2012; Ai et al., 2015). Watershed characteristics are also core factors in affecting stream water quality, as related to the importance of spatial features as causes or moderators of observed instream conditions (Johnson et al., 1997).

Variations in watershed characteristics and stream inflows often result in variations of hydrological conditions, thereby altering contaminant production, tape drive, and its delivery into streams (Xiao and $\mathrm{Ji}, 2007)$. As a result, watershed characteristics and stream inflows have been increasingly considered as factors affecting water quality in a variety of environments and different scales (e.g., Lecomte et al., 2009; Sullivan et al., 2010; Zhou et al., 2012; Antunes et al., 2016).

Exploring the relationship between watershed characteristics and seasonal variability of stream water contaminants has a considerable importance for watershed management. Seasonal variations of precipitation and surface runoff have a strong effect on flow rates and hence on the concentration of contaminants in the stream water (Vega et al., 1998).

The ability to predict the transport of contaminants in open channels (streams) is a major topic in many environmental projects, ranging from the accidental release of pollutants to the transport of non-point sources (Abderrezzak et al., 2015). Solute transport is controlled by a suite of hydraulic and geochemical processes, such as mixing, exchange with storage zones and biogeochemical reactions.

Water quality models are useful tools for determining contaminant plume behavior and impacts on water quality. Simulated scenarios are especially useful for accessing multiple possibilities and proactively developing response plans for rapid and appropriate actions if a contaminant event occurred (e.g., Henderson-Sellers, 1991; DiGiano and Grayman, 2014). Water quality models can be used to simulate hydrodynamics, heat transfer, and water quality processes in watersheds in order to predict the fate and transport of water constituents or contaminants. The models simulate contaminant concentrations and their spatial distribution together with natural water physical-chemical parameters, based on analytical or numerical procedures (Jeznach et al., 2016).

\footnotetext{
* Corresponding author at: ICT/University of Minho. Campus de Gualtar, 4710-057 Braga, Portugal.

E-mail address: imantunes@dct.uminho.pt (I.M.H.R. Antunes).
} 


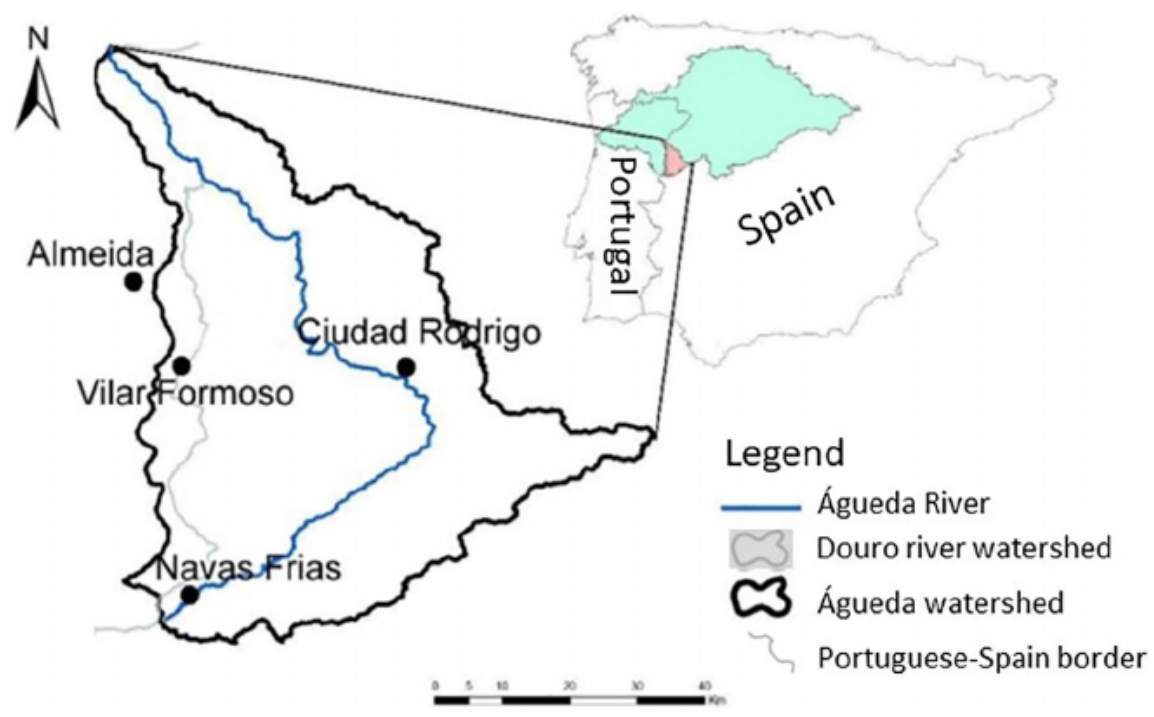

Fig. 1. Geographical setting of the Águeda transboundary watershed.

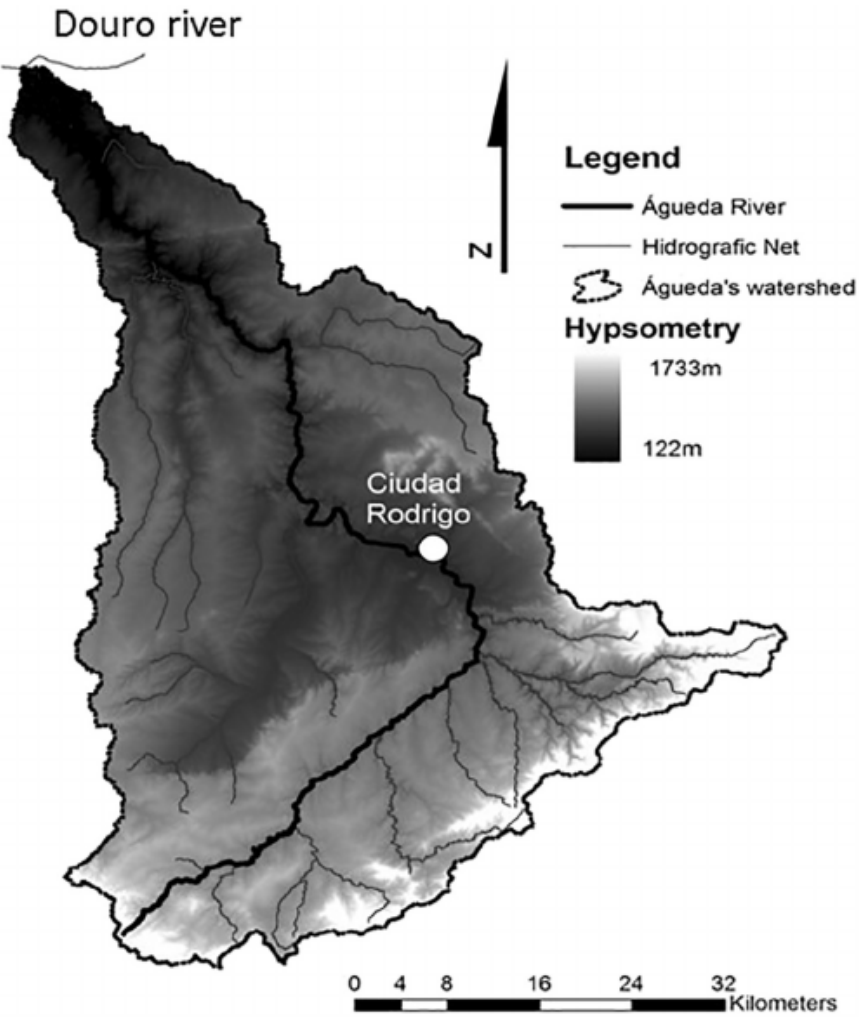

Fig. 2. Hypsometric map of the Águeda watershed.

A contaminant may enter in the watercourse as a topical or diffuse contribution. Topical contaminant sources are inputs occurring at a single location and may include inflows, such as those from a tributary or an accidental contaminant spill (Jeznach et al., 2016). Diffuse sources of contaminants can include surface contributions from a watershed, subsurface flow or atmospheric inputs. Diffuse pollution in agricultural watersheds is often significant sources of nutrients in the watercourse with considerable effects on water quality (e.g., Sharpley et al., 1994; Vorosmarty et al., 2007; Smith et al., 2017).

This case study introduces a framework based in water quality models to a better understanding of potential contaminant transport in surface water and to work as a tool for the development of appropriate emergency response and remediation actions, in a transboundary watershed (Portugal and Spain). The main objectives are: (1) characterize the Águeda river's spatial self-depuration ability; (2) simulate two different quality scenarios under the influence of a contaminant accidental topical discharge and a minimum flow rate condition (extremely dry year).

\section{Study area and data}

The Águeda transboundary watershed is in the central west of the Iberian Peninsula, extended between Portugal and Spain, and including the Spanish provinces of Salamanca and Cáceres $\left(2290 \mathrm{~km}^{2}\right)$ and the Portuguese municipality of Guarda $\left(310 \mathrm{~km}^{2}\right)$, with a total area of $2600 \mathrm{~km}^{2}$ (Fig. 1). The watershed covers 79 local municipalities and a population of 49,000 inhabitants, with Ciudad Rodrigo (Spain; 13,800 inhabitants) as the most significant urban area. The agriculture is the dominant activity (Albuquerque et al., 2013).

The Águeda River is a tributary of the Douro River, with about $144 \mathrm{~km}$ long (Fig. 1) and materializes the natural border between Spain and Portugal. Water flows heading north (Douro River), with a general SW-NE to S-N runoff direction and altitude varying between $1733 \mathrm{~m}$ (south) and $122 \mathrm{~m}$ (north) (Fig. 2). Three geomorphological units can be identified: a) southern steep area (slope ${ }^{>} 18 \%$ ), corresponding mainly to granitic rocks and to the highest hydrographic network's density; 2) central flat zone, constituted by sedimentary materials, and occupied mainly by agricultural activities; 3 ) northern zone of higher altitude, downstream the river catchment, with dominantly metamorphic rocks (Fig. 2). Almost the area is occupied by the Tertiary Ciudad Rodrigo's sedimentary aquifer (Instituto Geográfico Nacional, 2009). 


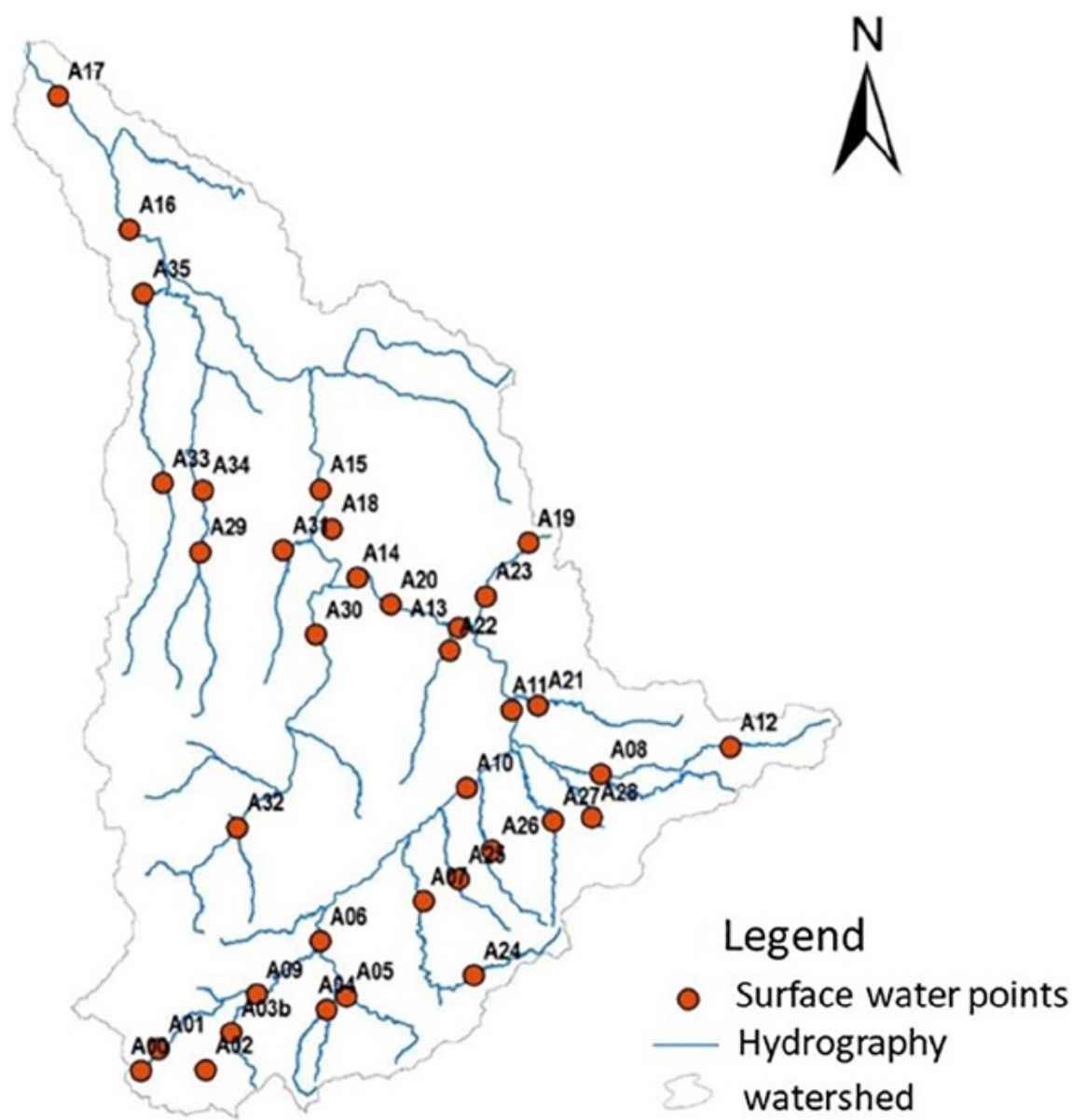

Fig. 3. Surface water sampling points.

The annual average temperature varies between $11.3^{\circ} \mathrm{C}$ and $16.0^{\circ} \mathrm{C}$. The higher total annual precipitation occurs in the south (about $1400 \mathrm{~mm}$ ) and overlaps the zones of higher altitude. The lower precipitation rate is observed in the central flat area, showing an average annual around $540 \mathrm{~mm}$ (Ninyerola et al., 2005).

Anthropogenic activities observed an exponential increase in the last 60 years. Natural resources' exploitation together with drastic changes in consumer habits induced significant environmental changes and deferred direct effects on natural habitats. The temporal land use evolution shows nowadays a distribution corresponding to $36.0 \%$ farms, $63.0 \%$ forests, pastures, and crags and $1 \%$ of urban areas and water bodies (Albuquerque et al., 2013).

Mineral resources occur distributed throughout the watershed and play a crucial role in environmental contamination. The main mineralization corresponds to sulfide and uranium minerals associated with granitic intrusions and a detrital iron material in a sedimentary rock (Sánchez-González et al., 2013). Mining activities constituted one of the principal human activities in the Águeda watershed area. Nowadays, almost all the mining activities have ceased, and there has not been any significant recovery processes. Tailings and rejected materials remain in open-pit accumulations, exposed to the atmospheric agents and water, triggering environmental geochemistry changes in surface streams and groundwater systems.

\section{Methods}

\subsection{Surface water sampling}

Along the Águeda transboundary watershed, thirty-six surface water samples were selected and collected (Fig. 3). The sampling sites are located along the Águeda River and its principal tributaries. For each surface water sample, temperature, $\mathrm{pH}$, dissolved oxygen (DO), electrical conductivity (EC), oxidation-reduction potential (ORP) and total dissolved solids (TSD) were determined "in situ" using a multiparametric portable meter. Chlorides, nitrites, nitrates, inorganic phosphates, sulfates, biochemical oxygen demand $\left(\mathrm{BOD}_{5}\right)$, chemical oxygen demand (COD) and trace element contents were analyzed by ultra-high liquid chromatography, in the Natural Resources and Agrobiology Institute (IRNASA, Salamanca; Spain). Selected parameters and chemical elements were applied to the surface water quality model. Biochemical oxygen demand, DO and microbiological parameters were selected as indicators for the presence of organic matter and used as parameters for evaluating water quality of the Águeda River and contaminant dispersion.

\subsection{Model data and calibration}

Self-purification or auto-depuration mechanisms are natural 


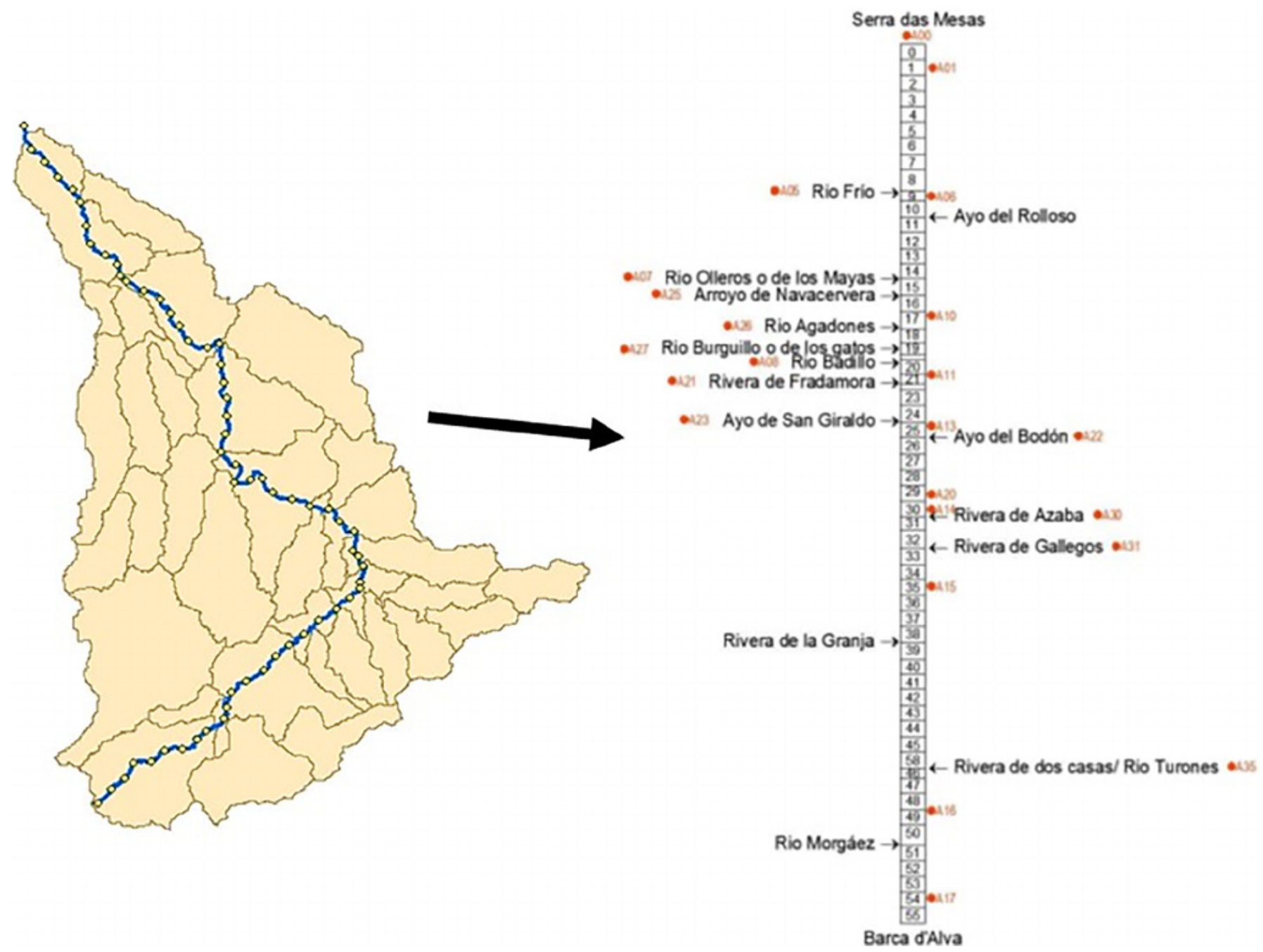

Fig. 4. Águeda River segmentation with topical inflows $(\rightarrow)$ and water sampling points (๑)

recovery processes of stream water, occurring under the influence of biodegradable organic matter discharges (Von Sperling, 1995; Sharma and Kansal, 2013). These mechanisms include physical (dilution and sedimentation), chemical (oxidation) and biological (decomposition of organic matter) processes. Persistent organic and inorganic compounds, such as metals, cannot be destroyed by auto-depuration mechanisms. Auto-depuration can thus be classified as a sequent ecological phenomenon, with a natural restoration of the watercourse (Von Sperling, 1995). The ability for auto-depuration varies with water body characteristics, amount of topical and/or diffuse discharges and type of contaminant (Oliveira, 2014).

The prediction model for contaminant dispersion characterization along a river is a crucial framework for water quality assessment. Computational methodologies allowed a huge increase in models complexity. The simulation of water quality is nowadays possible in 1D, 2D, and 3Dimentions. Some examples could be indicated: AQUATOX, BLTM (Branched Lagrangian Transport Model), EPD-RIV1 (One Dimensional Riverine Hydrodynamic and Water Quality Model), WASP 7 and WQRRS (Quality for River-Reservoir Systems) and QUAL2kw one of the most effective tools for modelling river water quality (Sharma and Kansal, 2013; Oliveira, 2014) and the adopted in the herein study case. QUAL2kw can simulate numerous parameters such as temperature, $\mathrm{pH}$, biochemical oxygen demand, dissolved oxygen, coliforms, among others (Pelletier and Chapra, 2008). The method starts with the river segmentation in sections with similar characteristics (e.g., slope, bottom's width, channel roughness, etc.) and numbered in ascending order. The first section located at the river spring and increasing downstream. All the tributaries are represented as topical inputs (Fig. 4). The Águeda River was modelled along all its course (about $140 \mathrm{~km}$ ), from spring to mouth, and considering 55 sections with a constant value of $2.5 \mathrm{~km}$ (Fig. 4).

The calibration was acceptable for all the analyzed parameters, with punctual variability in some water samples (e.g., A13, A15, and A20; Fig. 5) mainly due to the presence of outliers, such as the observed in temperature, DO, EC and $\mathrm{N}_{\text {total }}$ results (Fig. 5).

\section{Results}

Two hypothetical scenarios were computed for contaminant dispersion characterization to test the Águeda River auto-depuration 

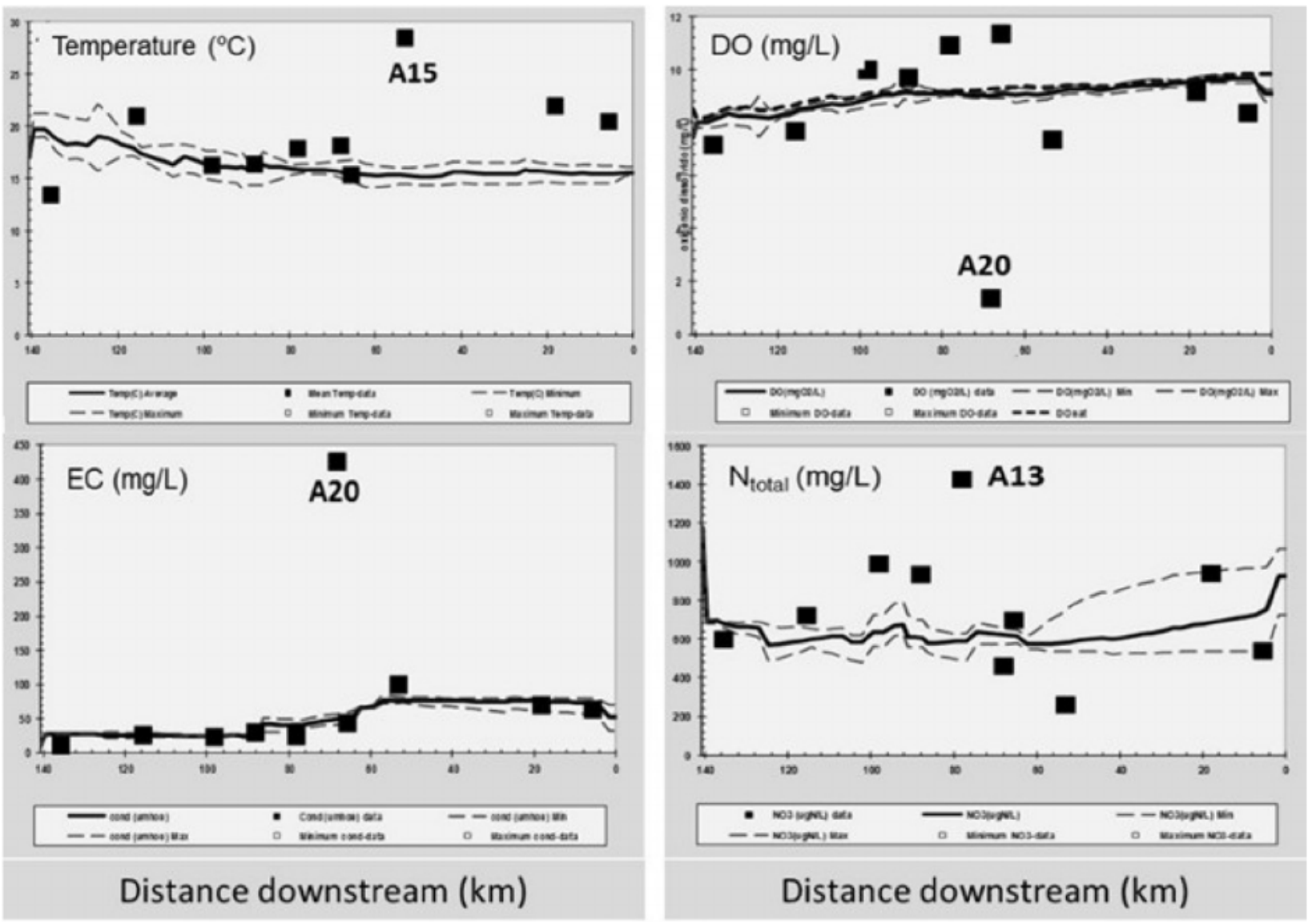

Fig. 5. Downstream calibrated model.

ability in face of the imposed changes. The first scenario - scenario 1 intended to assess the influence of contaminant accidental topical discharge, and the second one - scenario 2 - intended to assess the river behavior under minimum flow rates, representing an extremely dry year.

In scenario 1, the model was "forced" with a topical accidental discharge around Ciudad Rodrigo, corresponding to the most vulnerable area within the Águeda watershed (Albuquerque et al., 2013). The obtained simulated results for temperature, electrical conductivity, DO, $\mathrm{pH}, \mathrm{BOD}_{\text {fast, }}$ and $\mathrm{BOD}_{\text {ultimate }}$ are presented in Fig. 6. Almost all results show a change of behavior around the $84 \mathrm{~km}$, which is close to Ciudad Rodrigo and uranium mines. The more noticeable is concerning electrical conductivity, with the water's mineralization increase due to topical contaminant discharge (Fig. 6). However, there is not a significant impact on the water quality downstream river.

In scenario 2, a minimum flow rate, representing an extremely dry year, was considered. In this situation, even if a parameter variability, in water quality, can be observed downstream, globally water quality is not very significant change (Fig. 6).

The two considered scenarios revealed that self-depuration ability is more conditioned by the presence of minimum flow rates than by topical discharges, attesting a large potential for self-depuration along the Águeda River.

\section{Conclusions}

The water quality in the transboundary Águeda watershed was evaluated considering spatial contaminant dispersion under local variations. After reaching the optimum model calibration, it was possible to construct two prediction scenarios, imposing changes in the water quality parameters and in the fluvial system hydrology. With these two scenarios, it was possible to compute different images of the longitudinal water quality evolution under imposed stress. The model works as a predictive tool for water management support, allowing the implementation of corrective measures, in the short or in the long term, for a healthy ecosystem balance achievement, based on the evaluation of the simulated scenarios (Pelletier et al., 2006; Vieira et al., 2013).

In a future work, a more accurate data sampling will increase model calibration and therefore the water quality spatial distribution prediction under different expected stress scenarios in the Águeda River and its tributaries. 

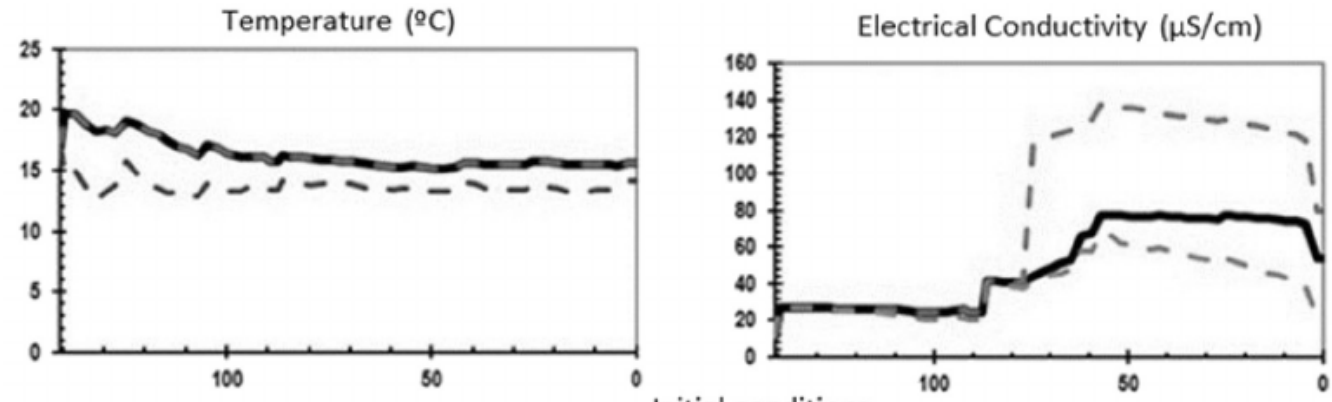

Distance to the river mouth Initial conditions

Distance to the river mouth

-- Scenario 1

$\mathrm{DO}(\mathrm{mg} / \mathrm{L})$ - - - Scenario 2

$\mathrm{pH}$

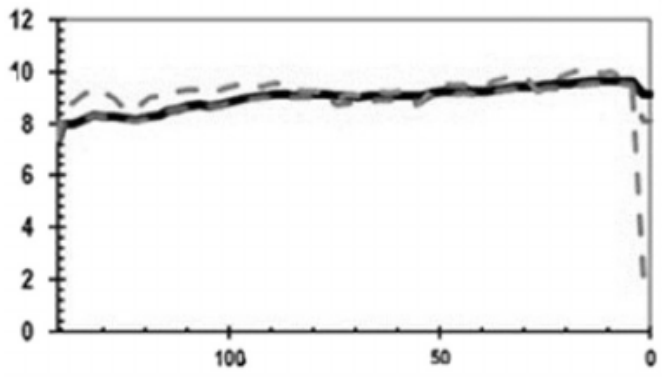

Distance to the river mouth

$B O D_{\text {fast }}(\mathrm{mg} / \mathrm{L})$

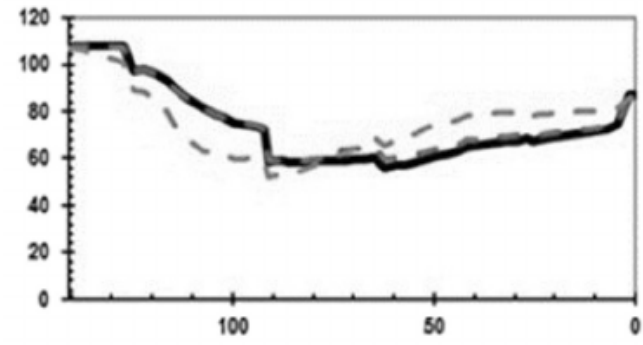

Distance to the river mouth

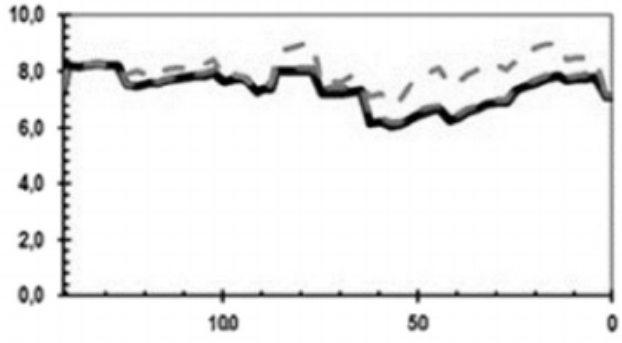

Distance to the river mouth

$\mathrm{BOD}_{\text {ultimate }}(\mathrm{mg} / \mathrm{L})$

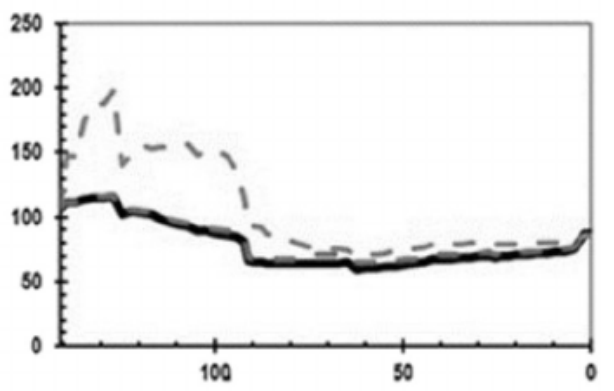

Distance to the river mouth

Fig. 6. Characteristics of surface water in two different simulated scenarios.

\section{Acknowledgments}

This research was funded by the POCTEP project "Caracterización ambiental y análises de riesgos em cuencas transfronteirizas: proyecto piloto en el río Agueda", 0410_AGUEDA_3_E. The author acknowledges the funding provided by the Institute of Earth Sciences (ICT), under contracts UID/GEO/04683/2013 with FCT (the Portuguese Science and Technology Foundation) and COMPETE POCI-01-0145-FEDER-007690.

\section{References}

Abderrezzak, K.E.K., Ata, R., Zaoui, F., 2015. One-dimensional numerical modelling of solute transport in streams: the role of longitudinal dispersion coefficient. J. Hydrol. 527, 978-989. http://dx doi.org/10.1016/j.jhydrol.2015.05.061.

Ai, L., Shi, Z.H., Yin, W., Huang, X., 2015. Spatial and seasonal patterns in stream water contamination across mountainous watersheds: linkage with landscape characteristics. J. Hydrol. 523, 398-408. http://dx.doi.org/10.1016/j.jhydrol.2015.01.082.

Albuquerque, M.T.D., Sanz, G., Oliveira, S.F., Martínez-Alegría, R., Antunes, I.M.H.R. 2013. Spatio-temporal groundwater vulnerability assessment - a coupled remote sensing and GIS approach for historical land cover reconstruction. Water Resour. Manag. 27, 4509-4526. http://dx.doi.org/10.1007/s11269-013-0422-0.

Antunes, I.M.H.R., Albuquerque, M.T.D., Seco, M.F.M., 2016. Avaliação da vulnerabilidade especial na água subterrânea. Las aguas subterráneas y la planificación hidrológica. In: Iberian Conference, Madrid, Spain. AIH-GE, SIBN: 978-84-938046-5-7.
DiGiano, F., Grayman, W.M., 2014. Can we better protect vulnerable water supplies? J. Amer. Wat. Works Assoc. 106, 28. http://dx.doi.org/10.5942/jawwa.2014.106.0067. Henderson-Sellers, B., 1991. Water Quality Modeling: Decision Support Techniques for Lakes and Reservoirs. CRC Presshttp://dx.doi.org/10.1016/j.geomorph.2009.04. 016.

Instituto Geográfico Nacional, 2009. Mapa Digital del Terreno. http://centrodedescargas. cnig.es/CentroDescargas/buscar.do (accessed 22 May 2012).

Jeznach, L.C., Jones, C., Matthews, T., Tobiason, J.E., Ahlfeld, D.P., 2016. A framework for modeling contaminant impacts on reservoir water quality. J. Hydrol. 537, 322-333. http://dx.doi.org/10.1016/j.jhydrol.2016.03.041.

Johnson, L.B., Richards, C., Host, G., Arthur, J.W., 1997. Landscape influences on water chemistry in Midwestern stream ecosystems. Freshw. Biol. 37, 193-208. http://dx. doi.org/10.1046/j.1365-2427.1997.d01-539.x.

Lecomte, K.L., García, M.G., Fórmica, S.M., Depetris, P.J., 2009. Influence of geomorphological variables on mountainous stream water chemistry (sierras Pampeanas de Córdoba, Argentina). Geomorphology 110, 195-202.

Ninyerola, M., Pons, X., Roure, J.M., 2005. Atlas Climático Digital de la Península Ibérica. Metadología y aplicaciones en bioclimatología y geobotánica. Universidad Autónoma de Barcelona (Spain), Bellaterra.

Oliveira, S.F.O., 2014. Caracterização das vulnerabilidades e riscos na bacia partilhada do rio Águeda. In: Ms Thesis. Polytechnic Institute of Castelo Branco, Portugal.

Pelletier, G.J., Chapra, S.C., 2008. QUALKw - a modelling framework for simulating river and stream water quality: theory and documentation. In: Manual Version 5.1. Department of Ecology, Olimpia, Washington.

Pelletier, G.J., Chapra, S.C., Tao, H., 2006. QUAL2Kw - a framework for modelling water quality in streams and rivers using a genetic algorithm for calibration. Environ. Model. Softw. 21 (3), 419-425. http://dx.doi.org/10.1016/j.envsoft.2005.07.002. 
Pratt, B., Chang, H., 2012. Effects of land cover, topography, and built structure on seasonal water quality at multiple spatial scales. J. Hazard. Mater. 209-210, 45-58. http://dx.doi.org/10.1016/j.jhazmat.2011.12.068.

Sánchez-González, S., García-Sánchez, A., Caravantes, P., Rodríguez-Cruz, M.S., SánchezMartín, M.J., Rodríguez, I.S.R., 2013. Caracterización y análisis de impactos ambientales en la cuenca del rio Águeda. In: Sánchez-Bordona, F.C. (Ed.), Cuenca del rio Águeda un território para dos Países. Servicio de Publicaciones. Universidad Europea Miguel de Cervantes Valladolid, Spain, pp. 35-64.

Sharma, D., Kansal, A., 2013. Assessment of river quality models: a review. Rev. Environ. Sci. Biotechnol. 12 (3), 285-311. http://dx.doi.org/10.1007/s11157-012-9285-8.

Sharpley, A.N., Chapra, S.C., Wedepohl, R., Sims, J., Daniel, T.C., Reddy, K., 1994. Managing agricultural phosphorus for protection of surface waters: issues and options. J. Environ. Qual. 23, 437-451.

Smith, L., Inmana, A., Laic, X., Zhang, H., Fanqiao, M., Jianbine, Z., Burkef, S., Rahn, C., Siciliano, G., Haygarth, P.M., Bellarby, J., Surridge, B., 2017. Mitigation of diffuse water pollution from agriculture in England and China, and the scope for policy transfer. Land Use Policy 61, 208-219. http://dx.doi.org/10.1016/j.landusepol. 2016.09.028

Sullivan, C.A., Reidy, Liermann, C., Davies, P.M., 2010. Global threats to human water security and river biodiversity. Nature 467, 555-561. http://dx.doi.org/10.1038/ nature09440.
Vega, M., Pardo, R., Barrado, E., Deban, L., 1998. Assessment of seasonal and polluting effects on the quality of river water by exploratory data analysis. Water Res. 32, $3381-3592$.

Vieira, J., Fonseca, A., Vilar, V.J., Boaventura, R.A., Botelho, C.M., 2013. Water quality modelling of Lis River, Portugal. Environ. Sci. Pollut. Res. 20 (1), 508-524. http://dx. doi.org/10.1007/s11356-012-1124-5.

Von Sperling, M., 1995. Princípios do Tratamento biológico de aguas residuárias Introdução à qualidade das águas e ao tratamento de esgotos. In: ABES v. 01. Minas Gerais, Brazil.

Vorosmarty, C.J., McIntyre, P.B., Gessner, M.O., Dudgeon, D., Prusevich, A., Green, P. Glidden, S., Bunn, S.E., Xiao, H., Ji, W., 2007. Relating landscape characteristics to non-point source pollution in mine waste-located watersheds using geospatial techniques. J. Environ. Manag. 82, 111-119. http://dx.doi.org/10.1016/j.jenvman.2005. 12.009.

Xiao, H., Ji, W., 2007. Relating landscape characteristics to non-point source pollution in mine waste-located watersheds using geospatial techniques. J. Environ. Manag. 82 (1), 111-119. http://dx.doi.org/10.1016/j.jenvman.2005.12.009.

Zhou, T., Wu, J.G., Peng, S.L., 2012. Assessing the effects of landscape pattern on river water quality at multiple scales: a case study of the Dongjiang River watershed, China. Ecol. Indic. 23, 166-175. http://dx.doi.org/10.1016/j.ecolind.2012.03.013. 